\title{
Bamboo Waste as Part of The Aggregate Pavement The Way Green Infrastructure in The Future
}

\author{
Mudjanarko Sri Wiwoho ${ }^{1},{ }^{*}$, Mayestino Machicky ${ }^{1}$, Rasidi Nawir ${ }^{2}$, Indrawan $^{1}$, and \\ Setiawan Ikhsan M. ${ }^{1}$ \\ ${ }^{1}$ Civil Engineering, Civil Department, Narotama University,Arief Rachman Hakim No. 51, Surabaya, \\ 60117,Indonesia \\ ${ }^{2}$ Civil Engineering, Civil Department, Polinema, Soekarno Hatta No. 9, Malang, 65141 Indonesia
}

\begin{abstract}
Paving block pavement is already widely used in Indonesia. Materials made of concrete paving blocks are easy to make and easy to implement. Currently the manufacture of paving blocks SNI 03-0691-1996 refers to a method that consists of a mixture of cement, sand/gravel: water. Our research uses bamboo pieces of waste material as a substitute for gravel. Comparison of the composition of the bamboo pieces that are used to dry conditions weighing $10 \mathrm{~kg}, 20 \mathrm{~kg}$ and $30 \mathrm{~kg}$. Based on compressive strength testing performed at the age of 7, 14 and 28 days can be known ability paving block receives compressive strength. The research using bamboo fiber material at 28 days had compressive strength $171 \mathrm{~kg} / \mathrm{cm}^{2}$, $190 \mathrm{~kg} / \mathrm{cm}^{2}$, and $199 \mathrm{~kg} / \mathrm{cm}^{2}$. While using bamboo fiber material and fly ash at 28 days have compressive strength $231 \mathrm{~kg} / \mathrm{cm}^{2}, 176 \mathrm{~kg} / \mathrm{cm}^{2}, 252$ $\mathrm{kg} / \mathrm{cm}^{2}$. Test results meet the quality of type C, D and the use of bamboo waste as aggregate paving can support green infrastructure in the future.
\end{abstract}

\section{Introduction}

Infrastructure is one of the most important things in the development effort and one of them is the use of paving material on the sidewalk. The availability of good infrastructure is very helpful for the implementation of economic development goals. The construction of sidewalks is one of the infrastructure to support community activities on foot. The sidewalks are still considered one eye in the development priorities as they are considered as supporting infrastructure and complementary roads. While the priority of development prioritizes the development of motor vehicle modes so that the infrastructure for pedestrians is forgotten. Though the sidewalk is an important pedestrian foot.

The role of the government is related to the provision of access and means for pedestrian protection from the activity of street vendors as it may disrupt the safe, comfortable and humane user community. The integration of pedestrian paths with the layout of the building, the accessibility between environments, and the transportation system in order to manifest well in the development stage for the future. These things

\footnotetext{
*Corresponding author: sri.wiwoho@narotama.ac.id
} 
certainly need to be handled from the government to pay more attention to the construction of roadside pavement that is more useful according to allotment. So far, paving is used as a sidewalk infrastructure. During this Paving does not penetrate / less response to water so easily damaged. During this paving is made from a mixture of concrete in the form of sand, cement, aggregate and mixed with water. The use of aggregate replacement materials is still rarely used, including the use of waste materials. [10] Sri Wiwoho Mudjanarko, 2016, conducted research on paving using bamboo aggregate ( compressive strength test pavement bamboo composite). Obtained research results obtained the largest compressive strength 192.29 with the use of $60 \%$ bamboo aggregate and meet the standards of quality SNI B. [6] M. Riang Endarto and M. Heri Zulfiar, 2010, in his research said that The greater percentage of bamboo aggregates in concrete mix, Then the value of compressive strength will be lower. The smallest average compressive strength value is 5.9 MPa that occurs in 100\% bamboo aggregate on conventional split aggregate. [3] Bangkit T., T, 2015, conducting preliminary research on paving Pervious concrete with average 28-day compressive strength Pervious concrete with code B1 105,11 kg/ cm2 and B2 100,30 kg / $\mathrm{cm}^{2}$ meet standard paving class D with average weight limit of $100 \mathrm{~kg} / \mathrm{cm} 2$ for the park road. And has a porosity / drain rate of 247.37 and $226.76 \mathrm{ltr} / \mathrm{mnt} / \mathrm{m}^{2}$. [7] Mokhammad Farid Ma'ruf, 2012, explains that the peak shear strength of bamboo root soil increases with increasing ground root volume ratio. Their relationship can be approached linearly. Although the root-to-ground volume ratio was investigated for only $5 \%$, the peak power peak ratio increased to 55\%. (The results show that peak shear strength of bamboo root reinforced soil increase with increasing soil root volume ratio.) Though soil-root volume ratio investigated was only up to $5 \%$, it generated up to $55 \%$ additional Peak shear strength). Bamboo has several limitations, namely the fiber is stiff and easily attacked by fungi and insects. From the limitations of the bamboo fiber, the writer wanted to know the extent to which this bamboo fiber is utilized to be an additional material in making paving block. Not only bamboo fiber in this study the author also memamfaatkan fly ash. As we know that fly ash is often utilized in research, especially research in the field of construction. Fly ash is produced from Ash / residual coal combustion which produces a residue called fly ash.

\section{Literature Study}

\subsection{Paving block}

Paving block is a building material product of cement used as an alternative cover or hardening of the soil surface. Paving blocks are also known as concrete blocks (concrete blocks) or cone blocks. Based on [9] SNI 03-0691-1996 paving block (concrete brick) is a building material composition prepared from a mixture of portland cement or similar hydrolysis, water and aggregate with or without other materials which does not reduce the quality of concrete bricks. As a cover material and hardening of the soil surface, paving blocks are widely used for various purposes, ranging from simple needs to use that require special specifications. Paving blocks can be used for hardening and beautifying street sidewalks in cities, hardening of streets in residential complexes or residential areas, beautifying gardens, yards and yard, hardening of parking lots, office areas, factories, parks and school grounds, as well as in hotel grounds And restaurants. Paving blocks can even be used in special areas such as container ports, airports, bus terminals and train stations. 
Table. 1 Quality Terms of paving blocks [9]

\begin{tabular}{|c|c|c|c|c|c|c|}
\hline \multirow[t]{2}{*}{ Quality } & \multirow[t]{2}{*}{ Used } & \multicolumn{2}{|c|}{$\begin{array}{r}\text { Compressive } \\
\text { strength }\left(\mathbf{k g} / \mathrm{cm}^{2}\right)\end{array}$} & \multicolumn{2}{|c|}{$\begin{array}{l}\text { Wear resistant } \\
(\mathrm{mm} / \mathrm{menit})\end{array}$} & \multirow{2}{*}{ 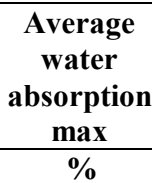 } \\
\hline & & Rate & Min & Rate & Max & \\
\hline $\mathrm{A}$ & Ways & 400 & 350 & 0,0090 & 0,103 & 3 \\
\hline $\mathrm{B}$ & Parking & 200 & 170 & 0,1300 & 0,149 & 6 \\
\hline $\mathrm{C}$ & Walking & 150 & 125 & 0,1600 & 0,184 & 8 \\
\hline $\mathrm{D}$ & Garden & 100 & 85 & 0,2190 & 0,251 & 10 \\
\hline
\end{tabular}

\subsection{Bamboo}

Bamboo is a plant derived from clumps of grasses with cavities and segments dibatangnya. Bamboo easily breed well. Bamboo plants around the world there are more than 80. [1] Agnes Dwi Yanthi Winoto, 2014. In Indonesia there are about 60 species of bamboo, commonly found in open places that are free from puddles. Bamboo is very productive because it has a high growth rate of about $3-10 \mathrm{~cm}$ per day. Bamboo plants are used as food, handicraft, and building construction. In addition, bamboo plants are used to improve water catchment. [2] Asih Ardianisa, 2013, Bamboo is a common tree used as one of the building materials and widely available in Indonesia. Approximately 1000 species of bamboo in 80 genera, about 200 species of 20 genera are found in Southeast Asia and in Indonesia there are 154 species of bamboo. Bamboo is an easily cultivated plant. Besides being easy to cultivate, bamboo has a high production amount of about 109.2 tons / ha / year. Bamboo has a very rapid growth with harvest periods ranging from 3-5 years. Bamboo can be utilized as building component such as pole, beam, floor, wall or bulkhead, ceiling, roof, buffer roof, door and others. The formation of this product generally does not use the entire stem section, resulting in a number of waste such as sawdust, shavings, tatal, and the bottom of the stem. Unused or wasted bamboo waste can reach $14.6 \%-33.5 \%$ or an average of $19.1 \%$. One of the needs of infrastructure materials is a strong paving, cheap and environmentally friendly. Various ways of using bamboo materials as an alternative material and already done research in civil engineering. Bamboo is a clump of grass (perreunial Grass) with woody stems (Woody steams, culus) so in other words the bamboo anatomy is very different from wood. The bamboo network consists of parathyelial cells and vascular groups (rich in reeds). This cluster consists of feathers, thick-walled fibers and pipes. The weakness of bamboo is a relatively short life span due to exposure to environmental changes, so the use of bamboo as a structural element should be capillary shield which is the fibers that give strength to the bamboo. The use of bamboo fiber provides only a small amount of compressive strength, since bamboo has a high wear and tear and shrink rate, and lower structural strength than conventional aggregates. Bamboo Fiber Size made with size $20 \mathrm{~mm}$ and diameter $1 \mathrm{~mm}$. The use of bamboo fiber makes it possible to produce paving lighter than paving using conventional aggregates.

\subsection{Fly ash}

[5] I.Nawaz, (2013). Fly ash is the remaining coal combustion in the form of amorphous fine particles, is an inorganic material formed from the change of mineral materials due to combustion process. From the coal combustion process in the steam generator unit (boiler) will form two types of ash namely: fly ash and bottom ash. The resulting coal ash 
composition comprises $10-20 \%$ bottom ash, while the remainder is about $80-90 \%$ in the form of fly ash captured by an electric precipitator before being discharged into the air through the chimne. Fly ash is produced from Ash / residual coal combustion which produces a residue called fly ash. Based on the International Journal of Innovative Research in Science, Engineering and Technology Fly ash is considered an amorphous and mineral mixture of Ferro-aluminosilicates. However, the main composition of fly ash depends on geographical factors related to the combustion conditions of coal and the type of ash. The main constituents of Fly ash are oxides, Si, Al, Fe, and Mg which constitute about $95-99 \%$ of the total fly ash constituents. [8] Mulyati and Saryeni Maliar, 2015, explained that to improve the quality of paving blocks, such as can be done by using mixed materials that can increase the compressive strength of paving block. Fly ash can be used as a material for the manufacture of artificial aggregates in concrete mixtures, paving block additives, mortar, brick, and lightweight concrete. Currently, fly ash is widely used for concrete mixtures, considering the fly ash contains pozzolan ingredients such as silicate and aluminate and a little calcium

\section{METHODOLOGY}

This study is an experimental research, which is doing different techniques and types of treatment in each group of research variables. The following research methods are presented in the flowchart below

\subsection{Flow chart}

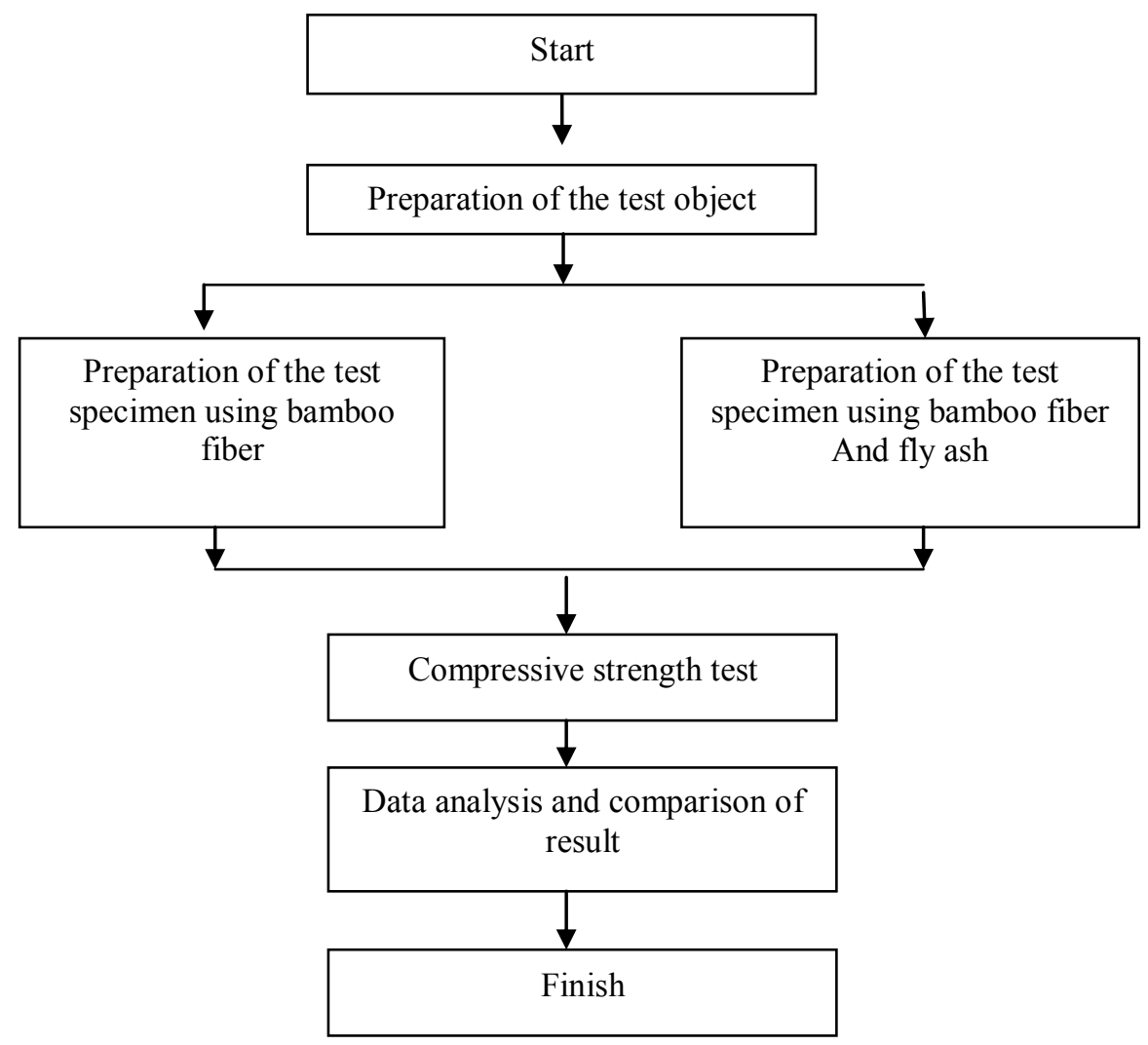




\subsection{The results of fine aggregate examination (sand)}

1. A fine aggregate gradation examination is performed to determine the variation of the aggregate grain distribution and the fine grain modulus number. Aggregates should have varying gradations, so that the pore volume between the aggregates formed becomes small. If the aggregate grains are uniform, the aggregate pore volume formed becomes large. The fine-grained modulus is an index used for the fineness or grain size of aggregate grains.

2. The dry type saturated sand (SSD) was 2.86 , while the water absorption from dry conditions was $4.2 \%$.

3. In this study the sand to be used for the mortar is sand under normal circumstances. Water content for sand under SSD condition is $4.2 \%$

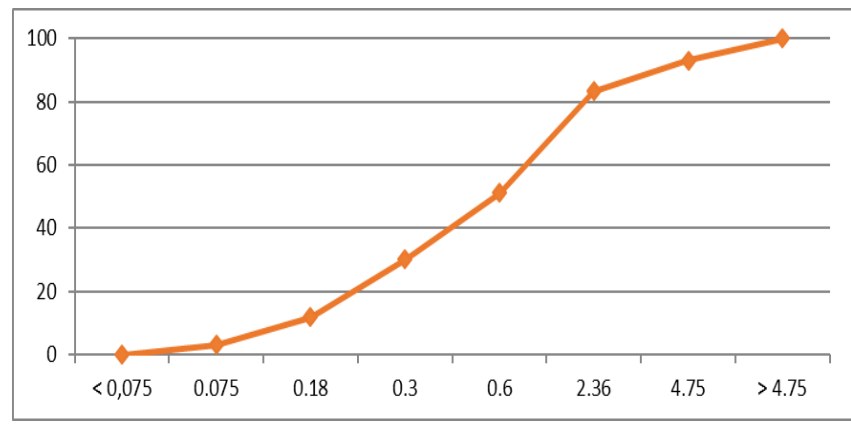

Fig. 1. Test gradation of sand

\subsection{Making bamboo fiber}

[4] Denny Nurkertamanda and Andi Alvin, 2012, At this stage are the steps to separate bamboo fibers to obtain the desired fiber, the best technique is a slow grinding process, aimed at separating between fiber binding and bamboo fiber. Pengrollan technique is different from beating, if the fiber roll is not interrupted due to beating too hard. If repeated emphasis techniques are applied, sometimes in some parts are missed. So the best technique of fiber separation is by either manual or with the help of mechanical roll. the manufacture of bamboo fiber is done by beating technique so that some bamboo fiber cut off due to beating

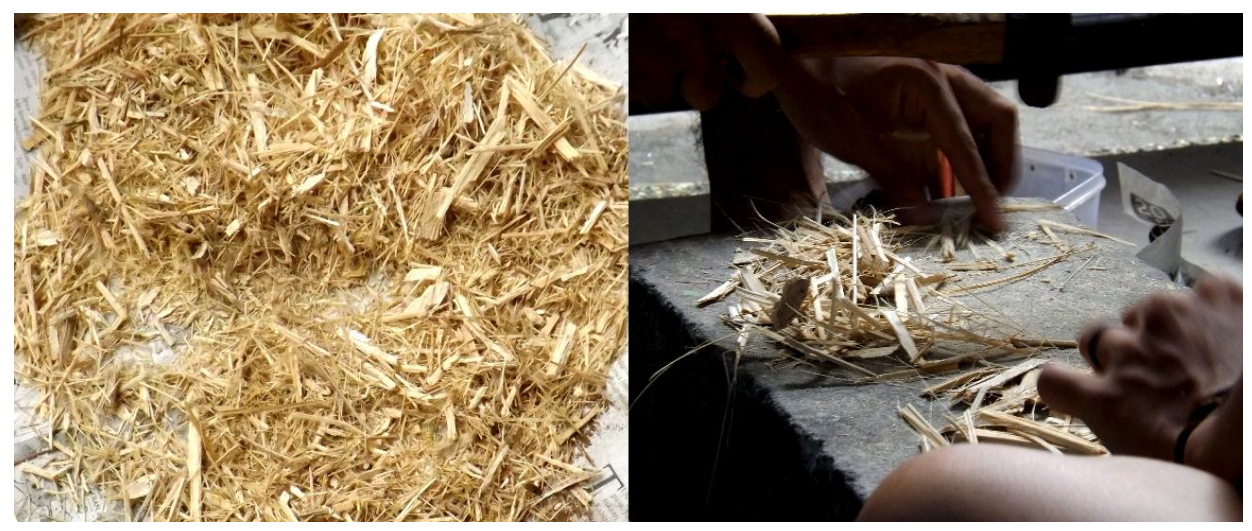

Fig. 2. Making bamboo fiber 


\subsection{Mix Design}

Below is a table composition of the material of cement, sand, water and bamboo fiber and fly ash in Table 2 and Table 3.

Table. 2 Mix Design paving with Bamboo fiber

\begin{tabular}{|c|c|c|c|c|}
\hline \multirow{2}{*}{ Material } & \multicolumn{4}{|c|}{ Percentage of material } \\
\cline { 2 - 5 } & $\mathbf{3 3 \%}$ & $\mathbf{6 7 \%}$ & $\mathbf{1 0 0 \%}$ & Unit \\
\hline Sand & 1200 & 1200 & 1200 & $\mathrm{Kg}$ \\
\hline Cement & 476,9 & 476,9 & 476,9 & $\mathrm{Kg}$ \\
\hline Water & 150 & 150 & 150 & $\mathrm{Kg}$ \\
\hline $\begin{array}{c}\text { Bamboo } \\
\text { fiber }\end{array}$ & 10 & 20 & 30 & $\mathrm{Kg}$ \\
\hline
\end{tabular}

Table. 3 Mix Design paving with Bamboo fiber

\begin{tabular}{|c|c|c|c|c|}
\hline \multirow{2}{*}{ Material } & \multicolumn{4}{|c|}{ Percentage of material } \\
\cline { 2 - 5 } & $\mathbf{3 3 \%}$ & $\mathbf{6 7 \%}$ & $\mathbf{1 0 0 \%}$ & Unit \\
\hline Sand & 1200 & 1200 & 1200 & $\mathrm{Kg}$ \\
\hline Cement & 476,9 & 476,9 & 476,9 & $\mathrm{Kg}$ \\
\hline Water & 150 & 150 & 150 & $\mathrm{Kg}$ \\
\hline $\begin{array}{c}\text { Bamboo } \\
\text { fiber }\end{array}$ & 10 & 20 & 30 & $\mathrm{Kg}$ \\
\hline Fly ash & 10 & 20 & 30 & $\mathrm{Kg}$ \\
\hline
\end{tabular}

\section{RESULTS ANALYSIS AND DISCUSSION}

\subsection{Effect of Bamboo Fiber to Percentage to Pressure Strength}

Bamboo fiber has an effect on strong compressive strength values. In this study with the use of bamboo fiber compressive strength reached the maximum limit at 28 days old with a value of $199 \mathrm{~kg} / \mathrm{cm} 2$. In this study, the percentage of material density if greater will increase in compressive strength in because bamboo fiber has a high enough density, which affects the compressive strength.

\subsection{Effect of Bamboo Fiber and fly ash to Percentage to Pressure Strength}

The use of bamboo fiber with fly ash in this penetration obtained value of maximum compressive strength of $252 \mathrm{~kg} / \mathrm{cm} 2$. In this study, the graph of compressive strength has increased with increasing age of paving 


\subsection{Compressive strength}

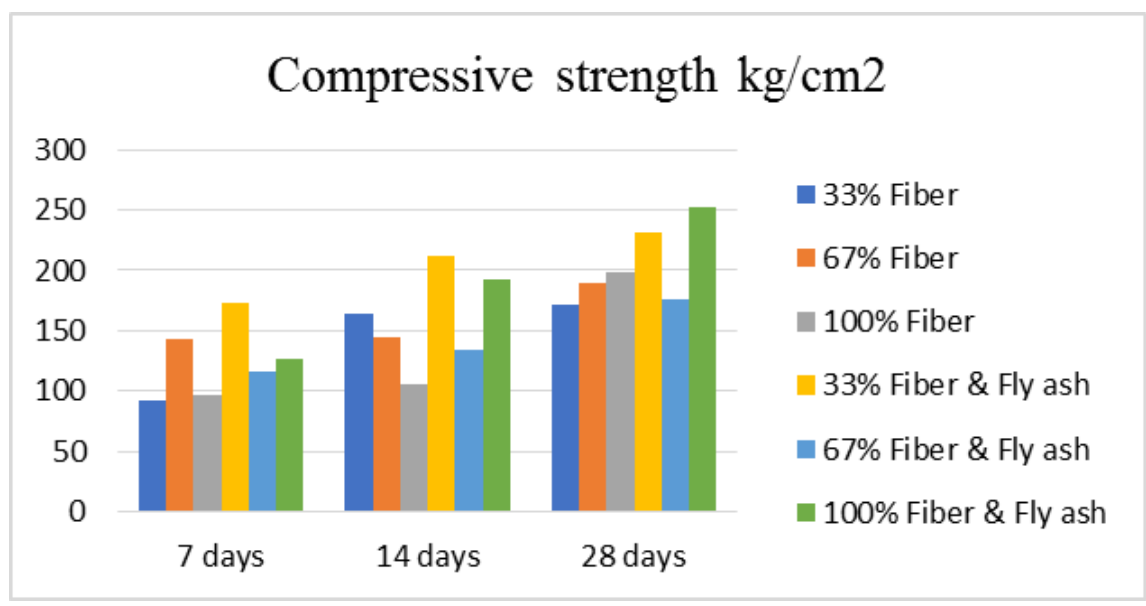

Fig. 3. Percentage Compressive Strength at age 7, 14 and 28 days
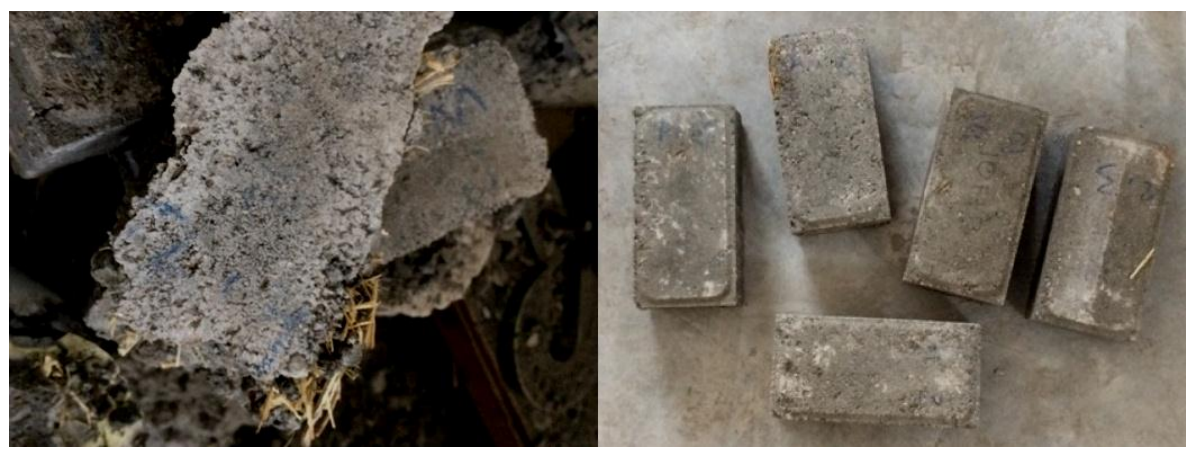

Fig. 4. Paving block

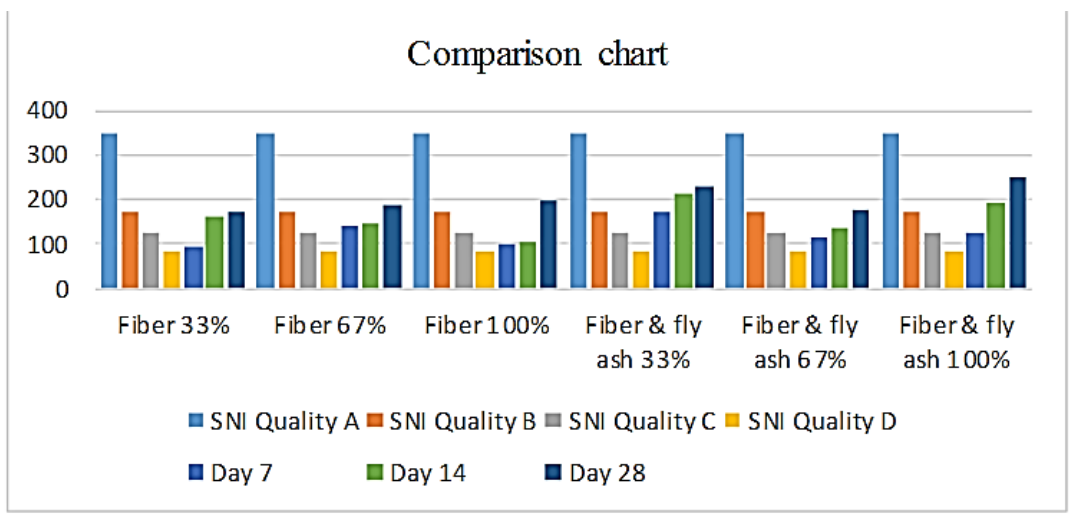

Fig. 5. Comparison of compressive strength with SNI 
The following summary:

1. The dose on paving using $100 \%$ bamboo and fly ash fibers has the greatest compressive strength value of $252 \mathrm{~kg} / \mathrm{cm} 2$ at 28 days, where this value is greater. Compared to paving using $100 \%$ bamboo fiber. In contrast to the researcher's expectations that the more bamboo used the smaller the resulting compressive strength

2. In paving with bamboo fiber and paving of bamboo fiber with fly ash does not have compressive strength reach $350 \mathrm{~kg} / \mathrm{cm} 2$ that is value of compressive strength of paving block at quality A, value of highest compressive strength of result of test object is $252 \mathrm{~kg} / \mathrm{cm} 2$ age 28 day, It is seen that paving blocks do not meet the standards on quality A

3. The value of compressive strength of paving block with class D quality can be achieved at 7 days

\section{CONCLUSION}

- The greater percentage of bamboo fiber in the paving mixture affects the compressive strength value being greater. The largest compressive strength value is $199 \mathrm{~kg} / \mathrm{cm} 2$ and the smallest compressive strength value is $92 \mathrm{~kg} / \mathrm{cm} 2$. Based on SNI the strongest value of the largest paving press meets the quality standard B and the smallest compressive strength paving value meets the quality standard D.

- The greater percentage of bamboo fiber and fly ash in the paving mixture affect the value of compressive strength becomes greater. The largest compressive strength value is $252 \mathrm{~kg} / \mathrm{cm} 2$ and the smallest compressive strength value is $116 \mathrm{~kg} / \mathrm{cm} 2$. Based on $\mathrm{SNI}$, the strongest value of the largest paving press meets the quality standard B and the smallest compressive strength paving value meets the quality standard $\mathrm{C}$

- Based from the compressive strength produced by all paving compositions with a mixture of bamboo fiber and bamboo fiber and fly ash, some of them already have compressive strength that meets the SNI 03-0691-1996 standard for use as sidewalks

\section{REFERENCE}

1. Winoto, A. D.Y., Konstruksi bambu untuk bangunan. Ensikopledia Teknik bangunan. ISBN: 978-602-7526-3 (2014)

2. Ardianisa, A, "Pengaruh Macam Katalis dan Ukuran Partikel Terhadap Sifat Papan Semen Limbah Bambu Petung, Skripsi”, UGM, (2013) http://etd.repository.ugm.ac.id/index.php?mod=penelitian_detail\&sub=PenelitianDetail \&act=view\&typ=html\&buku id=64443\&obyek_id=4 (2 april 2017)

3. Anoraga, Bangkit T.T., Mudjanarko, S.W., Kurniawan, F., "Desain Perkerasan Jalan Ramah Lingkungan Menggunakan Pervious Concrete Untuk Jalan Setapak Dan Area Parkir", Skripsi-Seminar Nasional Poltek Sriwijaya Palembang (2015)

4. Nurkertamanda, D., Alvin, A., Desain proses pembentukan serat bambu sebagai bahan dasar produk industri kreatif berbahan dasar serat pada ukm. J@ti Undip, VII, No 3, September (2012)

5. I.Nawaz. Disposal and Utilozation of fly ash to protect the Environment. International Journal Of Innovative Research In Science, Engineering and Technology. ISSN: 23198753.2, Issue 10, October (2013)

6. Endarto, M. R., Zulfiar, M. H.,Kajian eksperimen kuat tekan beton ringan menggunakan agregat bambu dan bahan tambah beton, 13, No. 1, 12-20 (2010) 
7. Ma'ruf, M.F., "Shear strength of Apus bamboo root reinforced soil", Ecological Engineering, 14, pp 84-86 (2012)

8. Mulyati., Maliar, S., Pengaruh penggunaan Fly ash sebagai pengganti Agregat terhadap kuat tekan paving block. Jurnal Momentum 17, No.1, Februari 2015, ISSN : 1693-752X

9. SNI-03-0691-1996, Tabel syarat mutu paving block, Badan Standardisasi Nasional (BSN)

10. Mudjanarko, S.W., et all, "Model Paving Pervious Concrete Berkombinasi Agregat Bambu Untuk Pelataran Parkir", Usulan Proposal Hibah Produk Terapan Ristek Dikti Tahun 2016. 